Jurnal Pengabdian dan

Penelitian Kepada Masyarakat

(JPPM)

\title{
PERAN MODAL SOSIAL DALAM PENGEMBANGAN DESTINASI WISATA "AEK BEDELEW" LEPAR DI KELURAHAN MANTUNG, KECAMATAN BELINYU KABUPATEN BANGKA
}

\author{
${ }^{1}$ Delia Febriana, ${ }^{2}$ Putra Pratama Saputra \\ 1'delliafeb@gmail.com; ${ }^{2}$ putraps92@gmail.com
}

\begin{abstract}
ABSTRAK
Seiring dengan perkembangan zaman, sektor pariwisata menjadi salah satu faktor yang patut untuk diperhitungkan, karena sebagai aset yang strategis untuk mendorong pembangunan wilayah yang memiliki potensi alam atau daya tarik wisata. Kecamatan Belinyu memiliki banyak potensi wisata alam yang jika dikelola dengan baik maka mampu meningkatkan perekonomian daerah. Salah satunya wisata aek bedelew yang baru-baru ini viral di media sosial di Bangka, dikelola oleh kelompok sadar wisata (pokdarwis) Greenboys. Pokdarwis greenboys memanfaatkan modal sosial sebagai strategi untuk mengelola destinasi wisata "aek bedelew" agar lebih dikenal luas oleh masyarakat. Pentingnya partisipasi masyarakat memberikan modal sosial dalam menjaga kawasan wisata agar tetap terjaga. Jadi modal sosial merupakan produk relasi manusia sebagai jaringan, norma, nilai, timbal balik dan kepercayaan yang berpotensi pada produktivitas masyarakat untuk pengembangan para anggota suatu kelompok masyarakat yang memungkinkan terjalinnya kerjasama diantara mereka dari suatu desa yang memiliki potensi wisata. Tujuan penelitian ini untuk menganalisis peran modal sosial dalam pengembangan destinasi wisata aek bedelew itu sendiri. Penelitian ini menggunakan metode kualitatif deskriptif yaitu menganalisis dan menyajikan data fakta secara sistematik sehingga dapat lebih mudah untuk dipahami dan disimpulkan. Dalam penelitian ini teknik pengumpulan data yang digunakan adalah teknik pengumpulan data primer dan sekunder berupa wawancara, observasi dan dokumentasi. Berdasarkan hasil penelitian modal sosial yang terdapat didalam kelompok sadar wisata (pokdarwis) Greenboys memiliki pengaruh positif dalam mengelola maupun mengembangkan wisata aek bedelew.
\end{abstract}

Kata kunci : destinasi wisata , modal sosial, pokdarwis

\section{ABSTRACT}

Along with the times, the tourism sector is one factor that should be taken into account, because it is a strategic asset to encourage the development of areas that have natural potential or tourist attraction. Belinyu district has a lot of natural tourism potential which, if managed properly, can improve the regional economy. One of them is "aek bedelew" tour which recently went viral on social media in Bangka., managed by the tourism awareness group Greenboys. Tourism awareness Greenboys utilizes social capital as a strategy to manage tourist destinations "'aek bedelew" so that it is more widely known by the public. The importance of community participation in providing social capital in maintaining tourist areas in order to stay awake. So social capital is a product of human relations as a network, norms, values, reciprocity and trust that has the potential for community productivity for the development of members of a community group that allows for cooperation between them from a village that has tourism potential. The purpose of this study was to analyze the role of social capital in the development of "aek bedelew" tourist destination itself. This research uses descriptive qualitative methods, namely analyzing and presenting factual data systematically so that it is easier to understand and conclude. In this study, the data collection techniques used were primary and secondary data collection techniques in the form of interviews, observation and documentation. Based on the results of research on social capital contained in the tourism awareness group Greenboys has a positive influence in managing and developing "aek bedelew" tourism.

Keywords: tourist destinations, social capital, tourism awareness groups 
Jurnal Pengabdian dan

Penelitian Kepada Masyarakat

(JPPM)

\section{PENDAHULUAN}

Di setiap daerah pastinya memiliki nilai lebih dan menjadi daya tarik tersendiri terhadap orang lain. Daya tarik tersebut merupakan hal yang memerlukan pengelolaan dalam pengembangan yang berkala dan berkelanjutan, karena dari hal yang sederhana tersebut masyarakat dapat mengambil manfaat sama halnya dengan bidang pariwisata, pengelolaan pariwisata dengan baik maka mampu untuk menghasilkan devisa pendapatan suatu daerah. Sektor pariwisata merupakan salah satu kegiatan yang memiliki nilai strategis dalam mendukung kegiatan pembangunan termasuk memperkuat urusanurusan lain yang berkaitan dengan pembangunan di daerah. Kehadiran sektor kepariwisataan bagi suatu daerah menjadi satu urusan yang dapat membuka ruang dan kesempatan dalam rangka memajukan kehidupan masyarakat terutama kali yang berhubungan dengan aktivitas ekonomi. Hal ini dikarenakan potensi pariwisata cenderung akan menimbulkan dampak yang positif terhadap berbagai aspek kehidupan di masyarakat (Afriyan, 2017).

Pembangunan pariwisata saat ini sedang di galakkan oleh pemerintah. Tujuan pengembangan pariwisata di Indonesia terlihat jelas dalam Instruksi Presiden Republik Indonesia Nomor 9 Tahun 1969, khususnya Bab II Pasal 3, yang menyebutkan "Usaha pengembangan pariwisata di Indonesia bersifat suatu pengembangan "Industri Pariwisata" dan merupakan bagian dari usaha pengembangan dan pembangunan serta kesejahteraan masyarakat dan negara" (A, Yoeti, 1996). Tentang Pembangunan Kepariwisataan Nasional Peraturan Pemerintah No 50 Tahun 2011 tentang RIPPARNAS 2010-2025 yaitu ada destinasi pariwisata, industri pariwisata, pemasaran pariwisata dan kelembagaan pariwisata (Deputi Bidang Pengembangan Destinasi dan Investasi Pariwisata, 2016). Menurut Pitana dan Gayatri (2005:96 dalam Setyawati 2015:5) ada banyak faktor yang berperan dalam menggerakkan sistem pariwisata tersebut. Aktor tersebut adalah insan-insan pariwisata yang ada pada berbagai sektor.
Secara umum, insan pariwisata dikelompokkan dalam tiga pilar utama yaitu : (1) pemerintah, (2) swasta, dan (3) masyarakat. Ketiga elemen ini harus bekerja sama dalam mengelola daerah wisata. Sektor pariwisata dapat menambah pendapatan daerah, hal ini dapat terjadi apabila pemerintah menempatkan masyarakat sebagai pelaku utama melalui pemberdayaan masyarakat di berbagai kegiatan kepariwisataan dan melibatkan masyarakat dalam pengembangan pariwisata. Sehingga pemanfaatan kepariwisataan sebesar-besarnya diperuntukkan bagi masyarakat itu sendiri. Dengan adanya peran serta masyarakat sebagai pelaku pendukung pariwisata, masyarakat menjadi memiliki peran yang sangat sentral dalam usaha untuk memajukan suatu kawasan yang akan dijual kepada konsumen dimana masyarakat bertanggungjawab atas pemeliharaan, kegiatan, serta manajemen dalam kawasan atau daerah tersebut. Terkait hal tersebut strategi pengembangan pariwisata yang dilakukan oleh Pemerintah daerah yaitu dengan membentuk Kelompok Sadar Wisata (Pokdarwis) dengan tujuan menjadi mitra pemerintah daerah dalam meningkatkan kunjungan wisatawan baik dari daerah itu sendiri maupun luar daerah.

Pada penelitian kali ini, penulis meneliti Pokdarwis greenboys secara lebih mendalam. Mengenai peran dan strategi mereka dalam memanfaatkan modal sosial untuk mengembangkan potensi wisata "aek bedelew" di kelurahan Mantung, Belinyu. Sebagai lembaga yang membidangi kegiatan pariwisata Pokdarwis Greenboys melakukan pendampingan, pembinaan kepada warga masyarakat terkait industri kepariwisataan, membuat paket wisata dan juga promosi untuk mengenalkan objek wisata yang ada di kelurahan mantung melalui media massa. Kehidupan sosial masyarakat di sekitar objek pengembangan pariwisata dapat menjadi sebuah modal sosial tersendiri yang berperan untuk memaksimalkan potensi yang ada sehingga menghasilkan dampak terhadap ekonomi yang juga lebih besar. Modal pengembangan objek pariwisata yang didapatkan dari kehidupan sosial masyarakat sekitar biasanya disebut dengan modal sosial. Modal sosial merupakan karakteristik organisasi sosial termasuk kemasyarakatan itu 
Jurnal Pengabdian dan

Penelitian Kepada Masyarakat (JPPM)

sendiri yang memfasilitasi dan mengkoordinasi kerja sama untuk mencapai suatu tujuan dan keuntungan bersama (Winarni, 2011).

Wisata "aek bedelew" yang baru-baru ini tenar hingga di media sosial merupakan tempat rekreasi baru yang sekarang menjadi ikon masyarakat di Kecamatan Belinyu, destinasi wisata "aek bedelew" memang terkenal dengan kejernihan air nya. Tak heran, banyak wisatawan yang datang untuk menikmati pesona aek bedelew ini. Aek bedelew memiliki luas kurang lebih 39 hektar dikelilingi susunan pohon gelam, akasia dan tumbuhan hutan lainnya yang berjejer rapi di sepanjang kawasan wisata ini, tanpa ada bangunan permanen satupun. Wisata aek bedelew dikelola dengan baik oleh kelompok sadar wisata (pokdarwis) Greenboys bekerja sama dengan KTH Kapitan Hijau. Mereka memanfaatkan potensi yang ada di areal $\mathrm{HKm}$ (hutan kemasyarakatan), untuk membatasi pergerakan oknum pembalakan liar dan tambang ilegal, serta dapat membantu perekonomian anggota dan masyarakat sekitar. Berbicara pembangunan didalam masyarakat erat kaitannya dengan modal sosial.

Modal sosial merupakan kemampuan masyarakat untuk bekerja sama, demi menjadi tujuan-tujuan bersama didalam berbagai kelompok dan organisasi (Coleman,1999). Pokdarwis greenboys memanfaatkan modal sosial sebagai strategi untuk mengelola destinasi wisata "aek bedelew" agar lebih dikenal luas oleh masyarakat. Berdasarkan wawancara peneliti terhadap ketua Pokdarwis Greenboys bahwasanya destinasi wisata aek bedelew merupakan salah satu destinasi baru yang banyak dikunjungi masyarakat. Berbagai strategi dalam pengembangan pariwisata yang melibatkan Pokdarwis sangat dibutuhkan, karena hal ini Pokdarwis Greenboys sangat berperan penting memajukan wisata aek bedelew. Maju atau tidaknya suatu objek wisata tergantung pokdarwis itu sendiri, karena pokdarwis nantinya akan mengelola serta turun langsung ke lokasi berinteraksi dengan para pengunjung.

Beberapa penelitian tentang strategi pengembangan destinasi wisata telah di pelajari secara luas oleh peneliti lain, salah satunya Arisya, Mutiara tentang Modal Sosial dalam Pembangunan Pariwisata (Studi Deskriptif pada Daerah Wisata Pemandian Air Panas Lau Debuk-Debuk di Desa Semangat
Gunung Kecamatan Merdeka Kabupaten Karo). Pengembangan pariwisata pemandian air panas sebagai salah satu produk wisata alternatif yang dapat memberikan dorongan bagi pembangunan pedesaan yang berkelanjutan. Serta pentingnya partisipasi masyarakat memberikan kontribusi sebagai modal sosial dalam menjaga kawasan desa agar tetap terjaga dengan baik sehingga mencapai keberhasilan dan berkembangnya pariwisata di desa Semangat Gunung. Sistem kekerabatan yang ada di Desa Semangat Gunung menjadi acuan utama dalam pembangunan pariwisata di desa ini. Penelitian ini menggunakan metode kualitatif dengan pendekatan deskriptif. Bertujuan melihat modal sosial yang ada dalam membangun Pariwisata Pemandian Air Panas Desa Semangat Gunung. Teknik pengumpulan data yang digunakan antara lain observasi, wawancara mendalam dan dokumentasi. Berdasarkan hasil dari penelitian ini yaitu pembangunan wisata air panas ini dimulai dari tahun 2000 sampai saat ini masih berjala dengan baik, meskipun hambatan yang terjadi karena sarana dan prasarana yang masih minim, cara yang dilakukan masyarakat dalam membangun pariwisata itu sendiri dengan modal sosial sendiri, adanya kerjasama diantara masyarakat yang memiliki usaha serta modal sosial yang dimiliki masyarakat Desa Semangat Gunung sangat mempengaruhi keadaan ekonomi bagi masyarakat desa ini.

$$
\text { Penelitian serupa tentang }
$$

pengembangan destinasi wisata juga dilakukan oleh Murniati tentang Partisipasi Masyarakat dalam Pengembangan Desa Wisata (Studi Deskriptif Kualitatif tentang Partisipasi Masyarakat dalam pengembangan Desa Wisata di Desa Wirun Kecamatan Mojolaban Kabupaten Sukoharjo). Penelitian ini dilakukan untuk melihat bagaimana proses pengembangan Desa Wirun sebagai desa wisata, selain itu penelitian ini bertujuan untuk melihat sejauh mana partisipasi masyarakat dalam mengembangkan desa wisata di Desa Wirun. Jenis penelitian ini menggunakan deskriptif kualitatif , berlokasi di Desa Wirun Kecamatan Mojolaban Kabupaten Sukoharjo. Pengumpulan data dilakukan dengan teknik wawancara secara mendalam. Setelah analisis teori partisipasi dari Roothman, telah dilakukan ketiga tahapan partisipasi yakni pembangunan loyalitas, perencanaan sosial 
serta aksi sosial. walaupun dari ketiga tahap tersebut telah dilaksanakan mulai darai sosialisasi, promosi, pembentukan Pokdarwis, kerja sama dengan hotel-hotel yang ada di Solo. Namun di masa tertentu hasil yang diinginkan tidak dapat tercapai, karena pengaruh krisis ekonomi dan keadaan politik di Indonesia, proses pengembangan desa wisata Wirun dikatakan mandeg atau stagnan, cenderung mengalami penurunan yang sangat signifikan menyebabkan wisata tersebut jarang dikunjungi.

Dari dua penelitian terdahulu yang dipaparkan diatas, dapat diketahui bahwa penelitian diatas memiliki perbedaan dengan penelitian ini. Penelitian terdahulu yang pertama membahas modal sosial yang digunakan dalam mengembangkan sektor pariwisata disuatu daerah sedangkan penelitian yang kedua membahas partisipasi masyarakat desa itu dalam membangun pariwisata namun nampaknya gagal atau kurang berhasil. Nah untuk penelitian kali ini penulis akan membahas mengenai strategi kelompok sadar wisata atau Pokdarwis dalam mengelola dan mengembangkan destinasi wisata, mencakup modal sosial masyarakatnya dalam membangun wisata baru di daerah peneliti sendiri. Dan penelitian ini menjadi penelitian perdana bagi penulis dalam melihat dan mengkaji secara langsung modal sosial masyarakat, melihat strategi-strategi seperti apa yang dilakukan oleh Pokdarwis Greenboys dalam mengelola, serta memasarkan wisata aek bedelew sehingga diminati banyak pengunjung. Penelitian ini dilakukan di daerah penulis sendiri jadi memudahkan penulis dalam melakukan kajian penelitian secara mendalam.

\section{Destinasi Wisata}

Destinasi pariwisata adalah suatu entitas yang mencakup wilayah geografi tertentu yang didalamnya terdapat komponen produk pariwisata (attraction, amenities, accebilites) dan layanan, serta unsur pendukung lainnya (masyarakat, pelaku industri pariwisata dan institusi pengembang) yang membentuk sistem yang sinergis dalam menciptakan motivasi kunjungan serta totalitas pengalaman kunjungan bagi wisatawan. Daerah tujuan wisata atau destinasi pariwisata adalah kawasan geografis yang berada dalam satu atau lebih wilayah administrasi yang ada didalamnya terdapat daya tarik wisata. Menurut Daryanto (1997 : 167) dalam kamus Bahasa Indonesia lengkap destinasi diartikan sebagai "tempat tujuan atau daerah tujuan dan dengan kata wisata, hal ini berarti tempat tujuan wisata. Suatu destinasi harus memiliki berbagai fasilitas kebutuhan yang diperlukan oleh wisatawan agar kunjungan seseorang wisatawan dapat terpenuhi dan merasa nyaman. Tersedianya berbagai fasilitas kebutuhan yang diperlukan akan membuat wisatawan merasa nyaman dan semakin banyak wisatawan yang berkunjung. Menurut Undang-Undang Nomor 10 Tahun 2009 Tentang Kepariwisataan, yang dimaksud dengan wisata yaitu kegiatan perjalanan yang dilakukan oleh seseorang atau kelompok orang dalam mengunjungi tempat tertentu untuk tujuan rekreasi, pengembangan pribadi atau mempelajari keunikan daya tarik objek wisata yang dikunjungi dalam jangka waktu sementara. Sedangkan pengertian pariwisata adalah berbagai macam kegiatan wisata yang didukung berbagai fasilitas serta layanan yang di sediakan oleh masyarakat, pengusaha, pemerintah dan pemerintah daerah.

\section{Peran \& Kelompok Sadar Wisata (Pokdarwis)}

Menurut Soerjono Soekanto (2007 : 212) mendefinisikan peran sebagai aspek dinamis dari suatu kedudukan (status). Maka peran Kelompok Sadar Wisata adalah sesuatu yang diharapkan pokdarwis itu sendiri untuk kebaikan, pengembangan, promosi pariwisata dan pembangunan pariwisata di lingkungannya. Yang dimaksud peran dalam penelitian ini yaitu peran Pokdarwis Greenboys dalam mengembangkan dan mempromosikan wisata aek bedelew seperti peran dalam menjalankan program-program kerja serta pengembangan sumber daya manusia. Pokdarwis adalah kelembagaan di tingkat masyarakat yang anggotanya terdiri dari para pelaku kepariwisataan yang memiliki kepedulian dan tanggung jawab serta berperan sebagai penggerak dalam mendukung terciptanya keadaan yang kondusif bagi tumbuh dan berkembangnya kepariwisataan serta terwujudnya Sapta Pesona dalam meningkatkan pembangunan daerah melalui kepariwisataan dan manfaatnya bagi 
Jurnal Pengabdian dan

Penelitian Kepada Masyarakat

(JPPM)

kesejahteraan masyarakat sekitar (Rahim, 2012: 16). Dalam penelitian ini Pokdarwis yang dimaksud adalah Pokdarwis Greenboys Kelurahan Mantung , Kecamatan Belinyu, Kabupaten Bangka.

\section{Teori Modal Sosial}

Modal sosial adalah serangkaian nilainilai atau normal-normal informal, seperti rasa saling percaya, saling pengertian, adanya jaringan, hubungan sosial, kesamaan nilai dan perilaku yang dimiliki bersama di antara para anggota suatu kelompok masyarakat yang memungkinkan terjalinnya kerjasama diantara mereka dan akhirnya mencapai tujuan bersama. Modal sosial dalam pembangunan pariwisata ini dapat diidentifikasi dalam cara kekeluargaan yang masih ada di masyarakat Kelurahan Mantung. Modal sosial tersebut sangat berpengaruh dalam proses pembangunan pariwisata tersebut.

Bourdie sebagaimana dikutip dari Syahra (2003) mendefinisikan modal sosial sebagai keseluruhan sumber daya baik yang aktual maupun potensial yang terkait dengan kepemilikan jaringan hubungan kelembagaan yang tetap dengan didasarkan pada saling kenal dan saling mengakui. Selanjutnya ia mengatakan bahwa besarnya modal sosial yang dimiliki seorang anggota dari suatu kelompok tergantung pada seberapa jauh kuantitas maupun kualitas jaringan hubungan yang dapat diciptakannya, serta seberapa besar volume modal ekonomi, budaya dan sosial yang dimiliki oleh setiap orang yang ada dalam jaringan hubungannya.

Jadi modal sosial merupakan produk relasi manusia sebagai jaringan, norma, nilai, timbal balik dan kepercayaan yang berpotensi pada produktivitas masyarakat untuk pengembangan para anggota suatu kelompok masyarakat yang memungkinkan terjalinnya kerjasama diantara mereka dari suatu desa yang memiliki potensi wisata. Modal sosial dalam desa ini memiliki karakteristik yang muncul dari seluruh jaringan yang memiliki fungsi sebagai kontrol sosial, sistem kepercayaan dan moralitas sistem yang komperehensif antara individu atau dalam suatu kelompok, organisasi, komunitas, daerah atau masyarakat.

\section{METODE}

Metode Penelitian yang digunakan dalam penelitian ini adalah metode penelitian kualitatif deskriptif. Menurut Moleong (2017) penelitian kualitatif dengan metode deskriptif yaitu penelitian yang bermaksud untuk memahami fenomena tentang apa yang dialami oleh subjek penelitian misalnya perilaku, persepsi, motivasi, tindakan secara holistik \& deskriptif. Dalam artian metode ini dilakukan dengan cara menggambarkan situasi yang sedang terjadi dalam suatu objek penelitian dan menjelaskan mengenai fakta-fakta yang terjadi di lapangan. Penelitian ini membutuhkan analisis data untuk menghasilakan keakuratan dalam penelitian. Pada dasarnya penelitian kualitatif ialah suatu prosedur penelitian yang menghasilkan data deskriptif ucapan maupun tulisan dan perilaku yang dapat diamati dari orang-orang (subjek) itu sendiri, karena analisis data yang dilakukan tidak untuk menerima atau menolak hipotesis (jika ada) melainkan berupa deskriptif atas gejala yang diamati (Wirartha, 2006). Dalam penelitian ini penulis menggunakan jenis penelitian deskriptif yaitu menganalisis dan menyajikan data fakta secara sistematik sehingga dapat lebih mudah untuk dipahami dan disimpulkan.

Untuk memperoleh data dan informasi dalam penelitian ini, maka diperlukan adanya alat pengumpulan data yang bertujuan untuk medapatkan informasi yang dapat menjawabkan permasalahan - permasalahan yang bersangkutan. Dalam penelitian ini teknik pengumpulan data yang digunakan adalah teknik pengumpulan data primer dan sekunder. Teknik pengumpulan data primer adalah peneliti melakukan kegiatan langsung ke lokasi penelitian untuk mencari data-data lengkap dan berkaitan dengan masalah yang akan diteliti. Pengumpulan data primer dilakukan dengan cara observasi dan wawancara mendalam terhadap informan seperti observasi atau pengamatan dilakukan secara langsung, dalam artian penulis terjun langsung mengamati masyarakat di kelurahan Mantung dalam mengembangkan wisata didaerah mereka. Sedangkan teknik pengumpulan data sekunder merupakan data yang diperoleh secara tidak langsung dari objek penelitian seperti melalui kajian kepustakaan yaitu berupa dokumen, jurnal, skripsi dan foto yang dianggap relevan dengan masalah yang di teliti. 
Jurnal Pengabdian dan

Penelitian Kepada Masyarakat (JPPM)

\section{HASIL DAN PEMBAHASAN}

Hasil penelitian adalah pengkajian ulang terhadap validitas hasil penelitian. Pembahasan hasil penelitian dapat dijelaskan sebagai pemikiran asli penulis untuk memberikan penjelasan dan interpretasi atas hasil penelitian. Menurut Ary (2007) pembahasan hasil penelitian adalah penafsiran hasil penelitian yang berkaitan dengan hipotesis. Hasil pengamatan merupakan isi bagian yang penting dari teks ilmiah. Hasil pembahasan mempunyai sifat objektif dan subjektif, sebagai pertimbangan atau acuan untuk dijadikan sebagai sebuah teori.

\section{Modal Sosial dalam masyarakat}

Modal sosial adalah modal yang
umumnya digunakan seorang untuk
berinteraksi antar masyrakat didalam atau
diluar suatu kelompok masyarkat.
Pembentukkan modal sosial yang terjadi didalam masyarakat dimanfaatkan dengan baik dalam kehidupan bermasyarakat tidak dapat jika hanya digunakan pada seorang diri. Meskipun para ahli mengartikan modal sosial berbeda-beda. Namun secara umum tidak memiliki makna yang berbeda dari masingmasing penjelasan tersebut. Didalam modal sosial umumnya dinilai sebagai interaksi yang terbangun didalam masyarakat mencakup kepercayaan, jaringan, nilai \& norma, interaksi, dan kerja sama. Struktur kewajiban masyarakat yang terbentuk dalam suatu kelompok akan mendapatkan sebuah tanggung jawab yang menjdi kewajiban bagi masingmasing individu tersebut. Hal itu dapat membangun tingkat kepercayaan yang tinggi antar individu didalam suatu kelompok, dan apabila semua masyarakat menjalankan fungsinya sesuai dengan tanggung jawab dan struktur yang telah dibuat didalam masyarakat itu sendiri. Ada tiga tipe modal sosial yaitu modal sosial mengikat (social capital bonding) yang memiliki karakteristik ikatan yang kuat atau adanya perekat sosial dalam suatu sistem kemasyarakatan. Pada umumnya berasal dari ikatan kekeluargaan, sahabat dan kehidupan bertetangga, serta anggota dalam modal sosial ini umumnya mmiliki interaksi yang insentif. Yang kedua yaitu modal sosial menyambung (social capital bridging) merupakan ikatan sosial yang muncul akibat reaksi atas berbagai macam karakteristik kelompoknya. Modal sosial tipe ini muncul karena adanya berbagai macam kelemahan yang ada disekitarnya, sehingga membangun kekuatan dari kelemahan tersebut. Terbentuknya modal sosial tipe ini karena adanya interaksi antar kelompok dalam suatu daerah dngan tingkatan yang relatif lebih rendah seperti etnis, kelompok agama serta tingkat pendapat tertentu. Sementara itu yang ketiga ada modal sosial mengait (social capital linking) adalah hubungan sosial yang dikarakteristikkan akibat adanya beberapa level hubungan dari kekuatan sosial maupun status sosial yang ada didalam masyarakat. Pada umumnya modal sosial mengait (social capital linking) terbentuk dari adanya hubungan formal antar berbagai pihak seperti bank, sekolahan, lembaga politik, pertanian, kepariwisataan dan lainnya. ketiga modal sosial tersebut dapat bekerja dalam kelemahan ataupun kelebihan dari suatu permasalahan yang ada didalam masyarakat. Tipe modal sosial tersebut dapat dijadikan serta digunakan untuk pendukung sekaligus dapat menjadi penghambat dalam ikatan sosial tergantung bagaimana individu atau masyrakat memakainya.

\section{Strategi Pengembangan Wisata Aek Bedelew}

Berkembangnya pariwisata di suatu daerah akan mendatangkan banyak manfaat bagi masyarakat, yakni secara ekonomis, sosial dan budaya. Namun, jika pengembangannya tidak dipersiapkan dan dikelola dengan baik, justru akan menimbulkan berbagai permasalahan yang menyulitkan atau bahkan merugikan masyarakat. Untuk menjamin supaya pariwisata dapat berkembang secara baik dan berkelanjutan serta mendatangkan manfaat bagi manusia dan meminimalisasi dampak negatif yang mungkin timbul, maka pengembangan pariwisata perlu didahului dengan kajian yang mendalam, yakni dengan melakukan penelitian terhadap semua sumber daya pendukungnya (Wardiyanta, 2006 :47). Dalam proses pengembangan dan pengelolaan destinasi diperlukan partisipasi masyarakat, dan harus ada penggerak untuk membangun wisata yang biasa disebut dengan Pokdarwis (Kelompok Sadar Wisata) . Keberadaan Pokdarwis sebagai suatu institusi lokal terdiri atas pelaku kepariwisataan yang memiliki 
Jurnal Pengabdian dan

Penelitian Kepada Masyarakat (JPPM)

e ISSN: 2775 - 1929

p ISSN: $2775-1910$
Vol. 2 No.1 kepedulian dan tangggung jawab untuk menjamin pelaksanaan desa wisata serta bergerak dibidang swadaya. Wisata "aek bedelew" yang baru-baru ini tenar hingga di media sosial merupakan tempat rekreasi baru yang sekarang menjadi ikon masyarakat di Kecamatan Belinyu, di samping memiliki air yang jernih dari aliran sungai Nek Naro, terdapat pula beberapa hiasan yang indah , disediakan berbagai spot foto yang menjadi perhatian para pengunjung. Destinasi wisata "aek bedelew" memang terkenal dengan kejernihan air nya. Tak heran, banyak wisatawan yang berbondong-bondong datang untuk menikmati pesona aek bedelew ini. Aek Bedelew menjadi salah satu lokasi wisata yang sedang hits sejak pandemi Covid-19 merebak di Bangka. Aek bedelew memiliki luas kurang lebih 39 hektar dikelilingi susunan pohon gelam, akasia dan tumbuhan hutan lainnya yang berjejer rapi di sepanjang kawasan wisata ini, tanpa ada bangunan permanen satupun. Beralamat di jln. Kapitan,berada di perbatasan antara kelurahan air jukung dengan kelurahan mantung di kecamatan Belinyu. Destinasi wisata ini sedang viral lantaran banyak dikunjungi wisatawan lokal dari berbagai daerah. Wisata aek bedelew ini dikelola dengan baik oleh kelompok sadar wisata (pokdarwis) Greenboys bekerja sama dengan KTH Kapitan Hijau. Mereka memanfaatkan potensi yang ada di areal $\mathrm{HKm}$ (hutan kemasyarakatan), untuk membatasi pergerakan oknum pembalakan liar dan tambang ilegal, serta dapat membantu perekonomian anggota dan masyarakat sekitar.

Begitu banyak strategi yang telah dilakukan kelompok sadar wisata (pokdarwis) Greenboys diantaranya mempromosikan wisata melalui media sosial, membuat spotspot foto untuk menambah daya tarik wisata aek bedelew, membuat kolam air bedelew mini untuk anak-anak diisi dengan bola-bola kecil dan aneka mainan lainnya. sebagai area wisata baru, aek bedelew cukup banyak peminatnya. Karena ukuran kolam air hanya sekitar 39 hektar maka untuk pengunjung dibatasi dan diterapkan sistem booking terlebih dahulu. Sejauh ini wisata aek bedelew masih dinikmati dan menjadi inceran masyarakat. Berbicara strategi, tak hanya selalu yang mulus-mulus, ada juga hambatan dalam mengelola wisata baru ini seperti keterbatasan fasilitas, baik sarana dan prasarana, seperti wc yang dikatakan kurang memadai, jalan yang kurang memadai dan spot-spot foto yang banyak rusak oleh pihak-pihak yang tidak bertanggungjawab dan masih banyak lagi. namun mereka tetap berusaha menampilan yang terbaik untuk para pengunjung wisata tersebut.

\section{Peran Modal Sosial terhadap Pengembangan Wisata Aek Bedelew}

Berbicara pembangunan didalam masyarakat erat kaitannya dengan modal sosial. Modal sosial merupakan kemampuan masyarakat untuk bekerja sama, demi menjadi tujuan-tujuan bersama didalam berbagai kelompok dan organisasi (Coleman,1999). Pokdarwis greenboys memanfaatkan modal sosial sebagai strategi untuk mengelola destinasi wisata "aek bedelew" agar lebih dikenal luas oleh masyarakat. Didalam modal sosial terdapat tipe modal sosial diantaranya modal sosial mengikat (social capital bonding), modal sosial menyambung (social capital bridging ) serta modal sosial mengait (social capital linking). Menurut Woolchock (2000) modal sosial mengikat (social capital bonding) merupakan tipe modal sosial yang memiliki karakteristik ikatan yang kuat / adanya perekat sosial dalam suatu sistem kemasyarakatan. Pada umumnya berasal dari ikatan kekeluargaan, sahabat dan kehidupan bertetangga. Anggota dalam modal sosial ini umumnya memiliki interaksi yang insentif. Pokdarwis Greenboys dibentuk karena anggota didalamnya sama-sama memiliki hobby yang sama yaitu peduli akan lingkungan dan alam sekitar. Pantai lepar yang dikenal kumuh, tak layak dikunjungi karena dikelilingi hutan. Namun beberapa tahun ke belakang Pantai Lepar kini sudah layak dikunjungi, dan menjadi pantai favorit di Belinyu. Mulai dikenal masyarakat lokal maupun luar, tim pokdarwis terus mempromosikan wisata pantai lepar, sedikit demi sedikit membangun spot foto sebagai daya tarik di pantai ini. Tidak jarang pantai lepar dijadikan tempat sebuah event-event penting. Seperti acara camping bersama, dan acara lainnya yang berkaitan dengan wisata alam. Hingga kini Pokdarwis Greenboys masih semangat menjalankan aktivitas mereka dalam mengelola pantai lepar tersebut. Pantai lepar dikenal karena keindahannya, lokasinya yang memungkinkan untuk membuat event penting itu juga menjadi 
salah satu keunikan pantai lepar itu sendiri. Apalagi setelah dikelolanya wisata baru yang diberi nama "aek bedelew". Wisata pemandian air tawar yang berada berdampingan dengan air pantai itu sendiri membuat banyak masyarakat yang penasaran dan datang berkunjung untuk mandi disana. Air yang jernih, dikelilingi pepohonan membuat air itu terlihat berkilauan saat disinari matahari, oleh karena itu dinamakan aek bedelew diambil dari bahasa Belinyu itu sendiri "bedelew" yang artinya berkilau. Bukan hanya keindahan wisata aek bedelew saja yang dijadikan fokus penelitian kali ini, namun juga membahas bagaimana masyarakat memanfaatkan modal sosial yang ada disana. Untuk modal sumber daya alamnya , tidak diragukan lagi begitu indah ciptaan yang maha kuasa, namun keindahan itu hanya sesaat jika tidak dikelola dengan baik dan benar.

Kelompok sadar wisata (Pokdarwis) Greenboys ini memiliki nilai kekeluargaan yang sangat kuat. Mereka sangat bersemangat membangun dan mengelola wisata ini agar dapat dikenal masyarakat luas. Selain itu dibidang ekonomi juga bisa menambah pendapatan masyarakat sekitar sebagai pengurus wisata itu. Berdasarkan wawancara singkat saya terhadap ketua Pokdarwis Greenboys, kalau adanya wisata aek bedelew ini cukup meningkatkan pendapatan. Pendapatan itu digunakan sebagai modal untuk mengelola daerah wisata itu sendiri bahkan bisa juga digunakan untuk membantu masyarakat yang kurang mampu. Jika ada event besar pasti devisa anggaran keuangan pokdarwis akan meningkat. Mereka anggota pecinta alam dan kelompok sadar wisata saling membantu dan bekerja sama dalam mengelola wisata aek bedelew hingga bisa dikenal banyak orang sampai saat ini. Melakukan gotong royong membersihkan pantai, membuat spotspot foto tambahan disana, hingga saat ini hal seperti itu masih dilakukan oleh pokdarwis Greenboys. Hal itu menunjukkan bahwa modal sosial itu ada dan sangat memberikan pengaruh terhadap pengembangan sebuah destinasi wisata. Bekerja sama, berinteraksi, saling percaya adalah kunci yang ada didalam modal sosial, dan penulis melihat modal sosial itu ada dan memiliki peran penting didalam sebuah kelompok sadar wisata dalam mengelola destinasi wisata. Pentingnya partisipasi masyarakat memberikan kontribusi sebagai modal sosial, menurut masyarakat sekitar wisata aek bedelew, mereka juga turut ikut berpartisipasi dalam kegiatan apapun yang berkaitan dengan daerah mereka, mendukung segala kegiatan yang dilakukan, dan ada juga pihak-pihak yang memberikan sponsor didalam sebuah rangkaian acara baik formal maupun non formal. Hal ini yang menyebabkan penulis ingin meneliti modal sosial yang ada didalam proses pengembangan destinasi wisata itu sendiri. Peneliti pun merasa senang untuk mengambil data karena pihak yang terkait selalu memberikan keluasaan dalam penelitian ini, dalam artian mereka menerima dan sangat mendukung penulis untuk meneliti daerah mereka. karena sangat jarang ada peneliti yang mau melakukan penelitian didaerah sini, masyarakatnya tergolong friendly, ramah dan terbuka. Hal ini dapat dilihat dari observasi langsung penulis terhadap objek penelitian. Mereka welome untuk di wawancarai dan memberikan pernyataan apa adanya, tidak di kamuflase. Hal ini tentu memudahkan penulis dalam mendapatkan data .

\section{SIMPULAN DAN SARAN}

\section{Simpulan}

Modal sosial yang terdapat didalam kelompok sadar wisata (pokdarwis) Greenboys memiliki pengaruh positif dalam mengelola maupun mengembangkan wisata aek bedelew. Saling bekerja sama merupakan kunci modal sosial didalam masyarakat. Jaringan sosial yang ada didalam masing-masingg anggota kelompok mampu menutupi kekurangan fasilitas. Wisata daek bedelew telah dikelola dengan baik namun memiliki sedikit kekurangan pada fasilitas seperti sarana \& prasarana yang kurang mendukung. Selain jaringan antar anggota kelompok, mereka juga membaur dengan masyarakat daerah tersebut, saling memiliki hubungan timbal balik untuk memajukan daerah mereka. selain mengatasi permasalahan yang ada didalam masyarakat, modal sosial juga mampu membangun trust (kepercayaan) yang kuat dalam masyarakat yaitu membuktikan bahwasanya wisata aek bedelew kini sudah dikenal masyarakat luas. Selain itu apabila dikelola dengan baik sebuah daerah wisata tentu akan dapat menumbuhkan 
Jurnal Pengabdian dan

Penelitian Kepada Masyarakat (JPPM)

potensi ekonomi baru yang bisa dirasakan manfaatnya oleh masyarakat sekitar. Jadi partisipasi masyarakat sebagai bentuk kontribusi modal sosial yang ada didalam setiap individu maupun kelompok masyarakat sekitar.

\section{Saran}

Dengan dikenalnya wisata ini membuat permasalahan baru muncul seperti banyaknya sampah disekeliling pantai saat adanya event-event besar. Maka dari itu penulis harap akan kesadaran para pengunjung wisata agar lebih menjaga kebersihan daerah wisata tersebut. Selain itu berkaitan dengan spot foto, agar kedepannya pokdarwis dan masyarakat sekitar dapat menemukan inovasi baru dalam membuat daya tarik akan wisata tersebut. Dan terakhir bagi para pengunjung, hati-hati untuk berkunjung ke wisata aek bedelew jika saat musim hujan, karena jalannya masih tanah kuning dan cenderung licin untuk dilewati. Semoga untuk ke depannya pemerintah lebih peduli dalam mendukung daerah wisata yang baru mau maju atau berkembang terutama didaerah wisata yang memiliki potensi sumber daya alam yang melimpah.

\section{DAFTAR PUSTAKA}

Kusuma, U.A. 2017. Peran Modal Sosial Dalam Pemberdayaan Masyarakat Nelayan Desa Bangsring Pada Objek Ekowisata Bangsring Underwater. Malang : Universitas Brawijaya

Yulianto, T.S. 2015. Modal Sosial Masyarakat dalam Pengembangan Pariwisata di Desa Wisata Petingsari dan Desa
Sambi Kabupaten Sleman. Tesis. Yogyakarta : Program Studi Magister Perencanaan Kota dan Daerah Universitas Gajah Mada.

Inayah. 2012. Peranan Modal Sosial dalam Pembangunan. Ragam : Jurnal Pengembangan Humaniora Politeknik Negeri Semarang Vol. 12 No. 1

A, Yoeti, Oka. 1996. Pengantar Ilmu Pariwisata. Angkasa. Bandung

Silalahi, Ulber. 2010. Metode Penelitian Sosial. Bandung : PT Refika Aditama

Soekanto, Soerjono. 2010. Sosiologi Suatu Pengantar. Jakarta : Rajawali Pers.

Ritzer, George \& Goodman, Douglas J. 2007. Teori Sosiologi Modern. (Edisi ke 6. Cetakan ke 4). Rawamangun-Jakarta : Kencana Prenada Media Group.

Sembiring, Junaidi. 2016. Strategi Komunikasi Pemasaran Objek Wisata Gundaling dan Pemandian Air Panas Semangat Gunung. Jurnal Simbolika/Volume 2/Nomor 1/Maret 2016.

Pitana, I Gede \& Putu G, Gayatri. 2005. Sosiologi Pariwisata. Yogyakarta : CV. Andi Offset.

Arisya, Mutiara. 2018. Modal Sosial dalam Pembangunan Pariwisata (Studi Deskriptif pada Daerah Wisata Pemandian Air Panas Lau DebukDebuk di Desa Semangat Gunung Kecamatan Merdeka Kabupaten Karo). Jurnal mahasiswa Universitas Sumatera Utara

https://bangka.sonora.id/read/502333617/objek -wisata-aek-lelap-bedelew-mutiarawisata-yang-lagi-naik-daun?page $=$ all

https://klikbabel.com/2020/07/19/menikmatiwisata-aek-lelap-bedelew-yang$\underline{\text { memukau }}$ 